\title{
Fiscal Risk in ASEAN
}

\section{Tony Makin}

A unique characteristic of the ASEAN economies most badly damaged by the Asian financial crisis of 1997-98 (Indonesia, the Philippines, Malaysia and Thailand - the ASEAN-4) was that fiscal policies and public debt levels had been relatively sound leading up to the crisis (see, among others, Makin, 1999 and Eichengreen, 2002). The origins of crises of this kind are usually deep-seated, related and the result of a momentum that has developed over time, although the specific events precipitating each crisis usually differ.

In ASEAN, the underlying causes were excessive international borrowing by domestic banks for unproductive projects, overvalued exchange rates and poor corporate governance. Before the crisis, implicit bank guarantees created widespread moral hazard and pegged exchange rate regimes encouraged foreign currency borrowing on the presumption that central banks were covering exchange rate risk. None of these factors however was directly related to the fiscal sector.

This contrasts with other severe financial crises experienced over the past decade by transition economies in Europe, such as Bulgaria, the Czech Republic, Russia and Ukraine, and by other emerging economies in Latin America, such as Argentina, Brazil, Ecuador and Mexico, where fiscal problems were indeed the root causes of the financial crises (see Hemming, Kell and Schimmelfennig, 2003). Most of these countries had primary (non-interest) fiscal deficits, or declining primary surpluses, and high public debt levels in the years immediately preceding their crises. Specific determinants of fiscal vulnerability were excessive off-budget spending, implicit liabilities, low tax ratios, widespread tax exemptions and expensive bail-outs of state banks.

Within the ASEAN-4 fiscal balances measured as a proportion of GDP worsened markedly after the original Asian crisis of 1997-98. This subsequently converted pre-crisis budget surpluses into deficits that were high by the standards of developed economies. In turn, these deficits created hefty levels of public debt and high budget deficits and debt raise numerous macroeconomic risks for economies at their stage of development.

For instance, excessive government borrowing crowds out domestic investment spending, limiting capital accumulation and economic growth through higher domestic interest rates. An escalating stock of public debt also increases the probability of default, compounding interest rate pressures via a risk premium demanded by international creditors. Governments facing uncontrollable interest servicing costs driven by rising public debt are therefore tempted either to default outright, which subsequently makes further government borrowing on reasonable terms very difficult, or to monetise public debt, thereby generating higher inflation.

Tony Makin is Professor of Economics at Griffith University. 
Outright default or large scale monetisation of public debt can spark capital flight, causing financial collapse. Indeed, capital flight may occur the moment investors judge the risk of default or monetisation has become too high. Moreover, domestic and foreign funds may abruptly exit if investors decide that investment and economic growth are being unduly stifled by a fiscally-induced interest risk premium.

Mindful of such risks, this paper examines key features of fiscal activity in the ASEAN-4 economies since the Asian crisis. The next section highlights trends in public expenditure, revenue, deficits and debt escalation before and after the original crisis. Principles of public debt sustainability are subsequently advanced and applied to recent data. Fiscal policy options for containing public debt levels are then canvassed, before concluding that fiscal vulnerability has displaced financial sector weakness as a major source of crisis risk in the region.

\section{Fiscal Activity in the ASEAN-4}

Public sector size varies within the ASEAN-4 whose combined GDP now exceeds \$US 500 million for a population over 370 million. Revenue raising efforts in the region are generally low by advanced economy standards, falling below the OECD average of well over thirty per cent. For Indonesia, the Philippines and Thailand, consolidated central government revenue is under twenty per cent of respective GDP's with Malaysia's revenue share being somewhat higher.

The accompanying charts compare average revenue and expenditure shares of ASEAN-4 central governments relative to GDP before the crisis (1992-1996), with shares during and after the crisis (1997-2003). Interestingly, revenue to GDP ratios fell in all economies post-crisis, due in part to falls in customs revenue as international trade was progressively liberalised throughout the region.

On the other side of the public accounts, central government expenditure as a share of GDP significantly increased across the region, although relatively less so in the Philippines, the economy least affected by the Asian crisis. In the Philippines however, the change in the public spending to GDP ratio masks a rise in current expenditure offset by a relative fall in capital expenditure.

The combination of lower central government revenue and higher central government expenditure shares post-crisis manifested in bigger budget deficits for these economies, as illustrated in the next chart. Most notably, since 2000 Malaysia and the Philippines have persistently posted deficits between four to six per cent of GDP.

Public debt to income ratios of these economies have accordingly risen well above pre-crisis levels and well exceed the average public debt to income ratio of advanced economies of around 25 per cent (IMF, 2003). The pre-crisis public debt stocks of ASEAN-4 members reflected historically different economic and financial experiences. For instance, the macroeconomic impact of the 1997-98 currency crisis was relatively small for the Philippines from which it emerged without the severe recessions that occurred elsewhere in the region. 
Figure 1: ASEAN-4: Revenue and Expenditure Shares 1992-1996

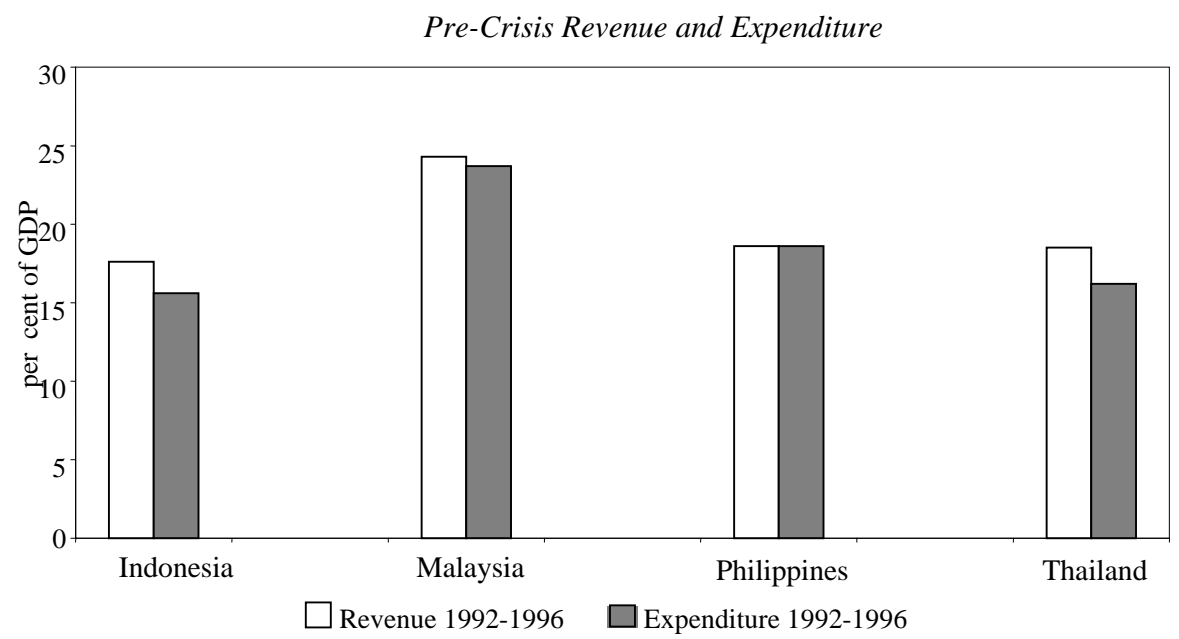

Source: Based on data from International Monetary Fund, International Financial Statistics and IMF-Singapore Training Institute.

Figure 2: ASEAN-4 Revenue and Expenditure Shares 1997-2003

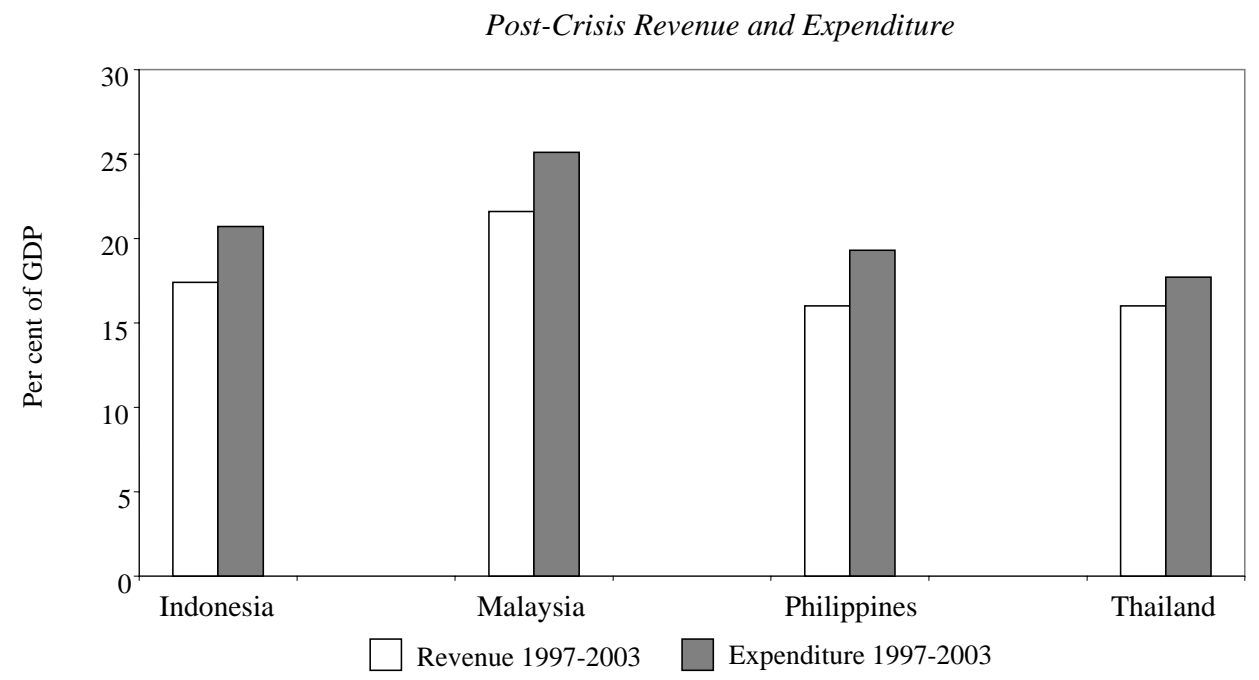

Source: Based on data from International Monetary Fund, International Financial Statistics and IMF-Singapore Training Institute. 


\section{Figure 3: Central Government Budget Balances, ASEAN-4}

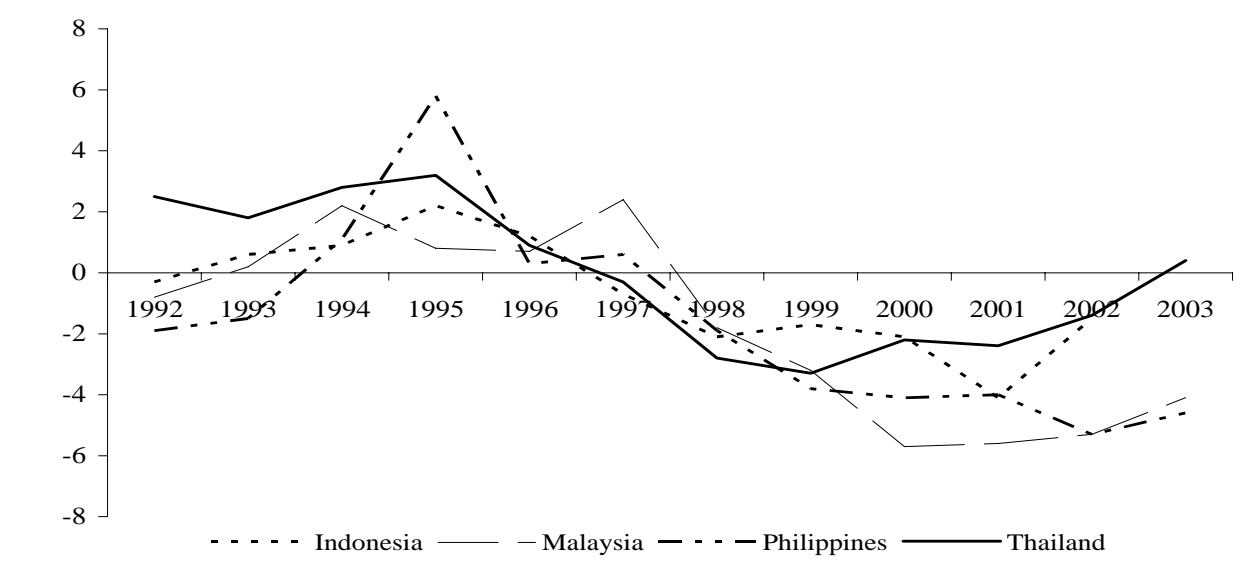

Source: Based on data from International Monetary Fund, International Financial Statistics and IMF-Singapore Training Institute

Yet the Philippines entered that crisis with the legacy of already high public debt stemming from an earlier serious fiscally induced crisis in 1985-86. Indonesia also experienced a potentially serious debt crisis in the mid-1980's when oil prices slumped. It weathered that period quite effectively but finished it with a high debt level.

Post-Asian crisis public debt levels grew strongly in the ASEAN-4 for numerous reasons. First, the massive currency depreciations during the crisis itself substantially raised the domestic currency value of foreign currency denominated debt. Second, governments deployed fiscal policy as a post-crisis countercyclical measure to boost domestic demand in the context of a global economic slowdown. However, the expansionary response across the region was tempered somewhat by IMF programs and the innate conservatism of ASEAN-4 finance ministers.

Third, accelerated domestic financial liberalisation facilitated issuance of public debt instruments in home markets over this time (IMF, 2003b). Finally, there was very significant 'socialisation' of private debt. In particular, when ASEAN-4 financial systems experienced balance sheet distress after their currencies collapsed, there was substantial recapitalisation of commercial banks, the fiscal cost of which was either recorded explicitly in the budget accounts or recorded off-budget through the quasi-fiscal activities of central banks or other government agencies.

In the aftermath of the crisis, sixty six banks were closed and a further thirty five financial institutions were nationalised, mostly in Indonesia (Brixi and Schick, 2002). Across the region, official deposit insurance schemes to protect bank depositors' funds either did not exist pre-crisis or were inadequate. Hence, during the crisis the public sectors of ASEAN-4 economies subsumed significant 
bank liabilities arising from implicit guarantees to protect depositors and other creditors, as well as foreign exchange debt of some corporations.

As a result, consolidated public debt (inclusive of the debt of all tiers of government and public enterprises) to GDP ratios rose to historically high levels, as shown in Figure 4. This was especially high for Indonesia and the Philippines near 80 per cent of GDP.

Figure 4: Consolidated Net Public Debt to GDP of ASEAN-4

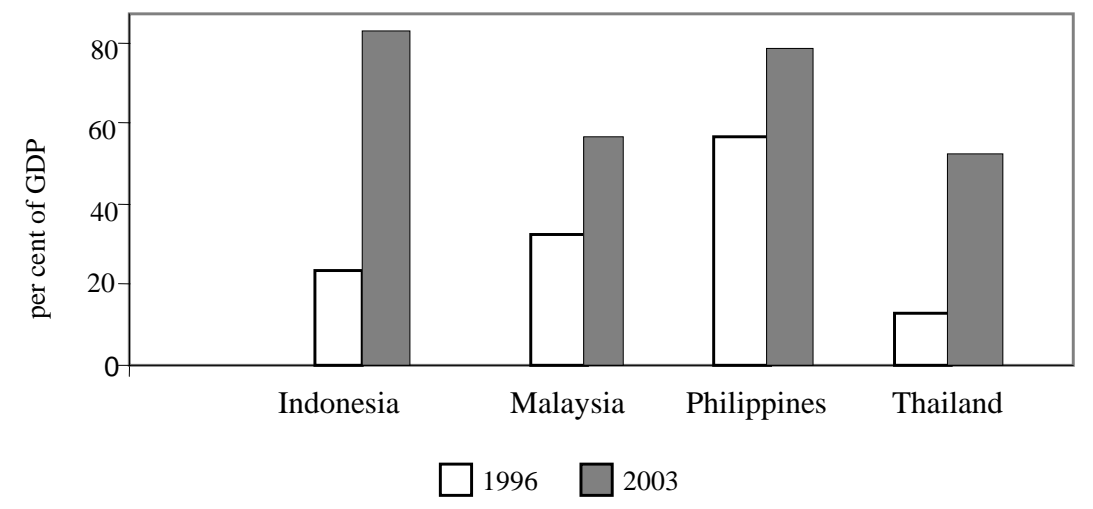

Source: IMF Singapore Training Institute

Despite reform efforts in the area, deposit insurance schemes in crisis-affected economies have still not been adopted uniformly throughout the region due to concerns about the incidence and size of insurance premiums to be levied and extent of depositor coverage such schemes provide (Demirguc-Kunt and Kane, 2002).

Since the crisis the individual fiscal experiences of ASEAN-4 economies have of course differed. For instance, in the Philippines political log-jams reflecting the influence of powerful vested interests have blocked congressional approval to raise so-called 'sin taxes.' These taxes are pegged at nominal amounts without any rise in rates. In Indonesia, by contrast, fiscal deficits have been reduced significantly, although political factors have prevented expenditure reduction, particularly to the huge petroleum subsidy which costs more than the entire development budget. Meanwhile, Malaysia has at times run quite high budget deficits, yet within an economy that posts high, partly compulsory, saving.

\section{Ascertaining Fiscal Sustainability}

A fiscal stance is ultimately not sustainable if it leads to an ever-increasing ratio of debt to income through time. To ascertain fiscal sustainability, it is necessary to estimate whether this ratio will rise, fall or remain stable in the immediate period ahead. Since the primary budget balance (the conventional fiscal balance less interest payments) determines the rate at which new debt accumulates or old debt 
can be retired, it plays the central role in assessing fiscal sustainability. The fiscal authorities can directly control primary budget balances through discretionary fiscal measures affecting public expenditure and revenue items.

A given fiscal stance is unsustainable if public debt to income exceeds a level financial markets will tolerate, although economic theory is unable to specify precisely what this limit is (see Aiyagari and McGrattan, 1998). It also varies from country to country, given levels of economic development and the underlying strength of financial systems.

Nonetheless, in light of rising public debt, fiscal authorities need to decide whether merely stabilizing, or reducing public debt is the critical policy objective. Having decided on a specific public debt to GDP ratio, it is then necessary to estimate what primary balance to national income ratio will ensure the target is met within an agreed time frame.

A useful macroeconomic accounting equation that indicates whether public debt is automatically increasing or decreasing is

$$
\Delta d=\left[\frac{i-g}{1+g}\right] d_{t-1}-p b .
$$

This standard equation shows that the public debt to income ratio (d) falls (rises), the lower (higher) the effective interest rate (i), the higher (lower) the rate of economic growth $(g)$ and the higher (lower) the primary (or non-interest) surplus $(p b)$.

To stabilise public debt to national income, the left side of the above equation must equal zero. Hence, the primary budget balance required for stabilizing the debt ratio is

$$
p b=\left[\frac{i-g}{1+g}\right] d_{t-1} .
$$

If the effective interest paid on public debt exceeds the growth rate, a primary surplus is required for debt stabilisation, whereas a primary deficit is possible if the growth rate exceeds the effective interest rate. If a primary surplus is necessary, its size rises directly with the magnitude of the initial debt to income ratio. Hence, the higher is the initial debt stock, the more difficult it is to stabilise the debt to income ratio and the higher this ratio, the greater is the fiscal effort required.

This perspective assumes no 'seigniorage' which occurs when budget deficits are money financed by the central bank. Seigniorage arises because governments have monopoly power to supply paper money whose printing cost is negligible. Through direct central bank funding of budget deficits, governments can use this power to acquire goods and services. Hence, it becomes an additional source of 'revenue'. Economic growth permits limited seigniorage without inflationary consequences if real money demand is growing along with real output.

However, the more important is money financing of deficits, the higher the 'inflation tax' has to be, as inflation reduces holdings of real money balances (the 'tax base'). Estimates suggest the maximum rate of seigniorage that is possible before money financing generates unwelcome inflationary pressures is between 1- 
2 per cent of GDP (see Fischer and Easterly 1990). Excessive money financing is highly inflationary and, for this reason, is prohibited in many countries.

Rising public debt levels can also potentially affect the household spending behaviour of households. In this context the Ricardian equivalence proposition is noteworthy. This proposition relates to a substitution between tax and bond finance holding public spending fixed. It implies that if households are forwardlooking, they could expect that higher future taxes will be necessary to repay public debt on maturity and hence would reduce consumption in anticipation of future tax obligations just as if the tax increase occurred in the present. Hence, substitution between tax and bond finance would have no real effects. Empirical evidence suggests, however, that Ricardian equivalence is of limited relevance to emerging economies (Bernheim, 1987).

\section{How Sustainable is ASEAN-4 Public Debt?}

Using recent data on budget imbalances, public debt levels, GDP and effective interest rates, it is possible to assess the sustainability of ASEAN-4 public debt levels. Specifically, the fiscal effort required to stabilise public debt levels in accordance with equation (2) can be gauged for each ASEAN-4 economy by combining recent data on debt to income ratios with effective interest rates on public debt and economic growth rates.

The effective interest rate is simply the ratio of public debt interest paid as a proportion of the total stock of public debt measured in domestic currency. It is sensitive to exchange rate movements as part of the stock of public debt of ASEAN-4 economies is denominated in foreign currency. Currency depreciations raise the effective rate, whereas appreciations lower it. Moreover, unless inflation is perfectly anticipated over the life of the nominal bonds on issue, the measure of the effective interest rate misses capital gains and losses on bonds.

Past public debt, budget deficit and interest data for the central government sectors of ASEAN-4 economies are available from Government Finance Statistics (IMF) and national accounts data from International Financial Statistics (IMF). Combining recent data yields values for central government primary (or noninterest) balances as a proportion of GDP that stabilise public debt levels. The hypothetical primary fiscal balances that stabilise debt may then be compared to actual primary balances. Recall that whenever actual values exceed the necessary stabilising values, public debt ratios must be falling, whereas if actual values are less than stabilizing values, public debt ratios must be rising.

Table 1, based on central government data only, provides estimates for 2004 of the central government primary balances that satisfy the stabilisation requirement specified in equation (2). These estimates can then be compared in the table with estimates of actual primary balances run by ASEAN-4 central governments. What the data show is that for each ASEAN-4 economy, the primary balance required to stabilise debt was smaller than the baseline primary balance. 
Hence, the data show that given recent macroeconomic conditions, public debt levels for Indonesia, Malaysia the Philippines and Thailand were not automatically escalating due to unstable debt dynamics.

Table 1: Debt Stabilisation and Primary Budget Balances, 2003-2004

\begin{tabular}{l|ccccc}
\hline & Debt/GDP & $\begin{array}{c}\text { Effective } \\
\text { Interest Rate }\end{array}$ & $\begin{array}{c}\text { Growth } \\
\text { Rate }\end{array}$ & $\begin{array}{c}\text { Stabilising } \\
\text { Primary Balance }\end{array}$ & $\begin{array}{c}\text { Estimated } \\
\text { Primary Balance }\end{array}$ \\
\hline Indonesia & 80.5 & 10.3 & 10.9 & -0.4 & 3.8 \\
Malaysia & 51.9 & 4.8 & 9.0 & -2.0 & -1.8 \\
Philippines & 71.7 & 7.8 & 8.6 & -0.5 & 0.9 \\
Thailand & 27.4 & 4.0 & 8.9 & -1.4 & 5.4 \\
\hline
\end{tabular}

Source: Based on data sourced from IMF, International Financial Statistics, Government Finance Statistics (various), Bank Negara and IMF Singapore Training Institute

The above empirical analysis may of course be further refined by reestimating stabilizing values using ranges for the key independent variables. Such sensitivity analysis would be necessary if the latest data was not considered representative of values expected over the medium term, although this is presently not the case.

Furthermore, it should be noted that the estimates of stabilising balances do not account for the debt of relevant provincial and local governments, public enterprises, or the outstanding off-budget debt of central banks that has arisen for the purpose of re-capitalising financial institutions in the wake of the Asian crisis. Hence, the above stabilising primary balances probably underestimate the fiscal effort required, although seigniorage, which has to be estimated separately using econometric techniques, would counterbalance the omission of the non-central government sector.

According to the above analysis, recent primary balances are preventing further escalation of ASEAN-4 public debt to income ratios. These levels of public debt and their associated interest servicing costs are still too high in light of the recommended 25 per cent debt to GDP limit advocated for emerging economies by the IMF (2003). Hence, merely stabilising public debt levels around recent peaks is not enough to lower fiscal risk in the region sufficiently.

In general, emerging economies have a higher risk of default and hence lower sustainable limits for public debt than advanced economies because their economies are more prone to natural disasters and terms of trade shocks, their financial markets are more volatile, credit histories are poorer and financial institutions are weaker. Moreover, in emerging economies without well established bank deposit insurance schemes, large contingent claims on the public sector further threaten sustainability through implicit blanket guarantees on bank deposits.

Half of recent debt defaults of emerging economies occurred at public debt levels below the 60 per cent limit set for European Union (EU) members. Based 
on previous fiscal crises in other emerging economies, a much lower debt to income limit for ASEAN economies of possibly half the EU limit may therefore be appropriate. ASEAN-4 economies are all well above such limits at present. The Philippines and Indonesia in particular, with public debt to GDP ratios of 80 per cent or more on a consolidated basis therefore need to exert substantially more fiscal effort to lower their public debt ratios substantially over the medium term.

\section{Fiscal Policy Options}

In sum, although the above analysis suggests that central government public debt ratios are not automatically growing under current macroeconomic conditions, the problem remains that existing debt levels currently well exceed prudent limits. Given the scale of public indebtedness, ASEAN-4 governments in general therefore need even larger primary surpluses than those recorded over recent years to minimise the risk of a fiscal-induced crisis.

Mounting theoretical and empirical evidence suggests that reduced budget deficits accelerate economic growth when public debt is too high and that reduced budget deficits may actually be expansionary. (See for instance Giavazzi, Japelli and Pagano, 2000). This is contrary to conventional Keynesian tenets about the stimulatory impact of higher government spending on aggregate demand and hence national income.

Lower budget deficits can of course be achieved through public expenditure restraint, improved revenue-raising or both. In theory, if fiscal consolidation occurs through reduced government consumption spending, other things equal, domestic saving would rise, domestic interest rates and any risk premium would fall and asset prices would strengthen. Lower interest rates stimulate private investment and consumption directly, by lowering the cost of financing them, and indirectly through wealth effects arising from higher asset prices.

However, there is likely to be less scope for fiscal adjustment of this kind on the expenditure side of ASEAN-4 budgets than in advanced economies, given a large non-discretionary element for essential services. Moreover, an expansionary effect is unlikely if public expenditure reduction impinges on capital items dedicated to growth-enhancing infrastructure development. Basic economic infrastructure is highly capital intensive and long-lived and includes roads, railways, ports and airports, as well as provision of electric power, gas, telecommunications, sanitation and water.

If based on cost-benefit evaluations, this spending can lift labour productivity and multifactor productivity, encouraging more private investment (see Munnel, 1992). Hence, an economy's infrastructure and the services it generates can be central to overall economic performance and living standards. In this regard, considerable long term finance for infrastructure is available from international institutions at highly concessional rates for the poorer ASEAN members. In Indonesia's case however, due to strong nationalist views held within the government development banks have been operating below their lending targets. 
A broader definition of infrastructure could also include spending on essential social services such as education and health care which potentially raise the productive value of an economy's stock of human capital. Hence, in the case of the ASEAN-4, rather than curtailing public spending that assists development and growth, increasing public revenue merits greater attention.

Revenue shares in the region are generally low by international standards and have actually fallen in the Philippines and Thailand post-crisis. The main remedial fiscal focus could therefore be on broadening revenue bases through new tax policies and administrative reforms.

Specifically, this could result in a wider application of value-added taxes and increased income taxes with fewer exemptions, formidable tax administration problems notwithstanding, including those related to corruption and tax avoidance. Of course, raising extra revenue imposes additional direct and indirect economic costs, but such costs are likely to be significantly less than the macroeconomic costs and further fiscal outlays that would accompany another financial crisis and recession.

Adopting explicit fiscal rules defined in terms of one or more fiscal flow or stock variables would also impose greater discipline. For instance, ASEAN fiscal authorities could announce explicit debt to income targets to be met over the medium term, akin to inflation targeting regimes now constraining the central banks of the Philippines and Thailand. Having achieved sustainable debt levels, upper limits could then be set for budget deficits, such as those that have governed fiscal policy in the European Union.

A rule could also decree that current public spending always be covered by revenue and that borrowing only be allowed for capital spending (the so-called 'golden rule'). Such measures would safeguard policy credibility in the region and counter the tendency of governments to accumulate debt that future generations will have to repay.

\section{Conclusion}

Operating with financial systems substantially restructured in the wake of the Asian crisis, Thailand, Malaysia, Indonesia and the Philippines in the main display greatly renewed economic vigour. However, public debt levels in these economies considerably exceed pre-Asian crisis levels due to persistently large fiscal deficits and the legacy of bank re-capitalisation measures. The vulnerability to financial crisis stemming from investor reaction to the commercial practices adopted by ASEAN financial institutions may have lessened, but has been supplemented by fiscal risk.

With internationally integrated financial markets, domestic and foreign investors need only anticipate future debt monetisation or default for immediate capital flight to spark a liquidity crisis in the domestic financial systems, necessitating stringent fiscal consolidation. In this way, high public debt has directly contributed to financial crises in emerging economies in central Europe and Latin America over the past decade. 
ASEAN-4 public debt levels are still high by the standards of most advanced economies and unexpected rises in world interest rates or sharp currency depreciations in the region would severely test public debt sustainability. It may of course be argued that the crisis within ASEAN (and South Korea) of the late 1990's itself could have been triggered by foreign investors foreseeing the more recent fiscal deficits rather than the deficits being the response to the crisis. The evidence suggests however that the plunge in demand for ASEAN assets was mainly due to domestic and foreign investors losing confidence in the ability of the corporate sector to service loans and in the capacity of the banking system to finance deposit outflows.

Central and provincial governments in the ASEAN-4 could also further strengthen institutions and processes governing the conduct of fiscal policy by enacting fiscal responsibility laws as permanent institutional stratagems for ensuring fiscal discipline and enhancing the predictability, credibility, and transparency of fiscal policy. Such laws, which have proven successful in New Zealand (Fiscal Responsibility Act 1994), Australia (Charter of Budget Honesty Act 1998), the United Kingdom (Code for Fiscal Stability, 1998), and more recently in Brazil, exemplify best fiscal practice internationally.

To sum up, large post crisis fiscal deficits and financial sector restructuring have substantially raised public debt levels in Indonesia, Malaysia, Thailand and the Philippines. Fiscal vulnerability has therefore displaced financial sector weakness as a key source of crisis risk, especially for the Philippines and Indonesia. Achieving significantly higher primary surpluses in these economies would lower the risk of another regional financial crisis rearing up in a different guise.

\section{References}

Aiyagari, R. and E. McGrattan (1998), 'The Optimum Quantity of Debt', Journal of Monetary Economics 42(4):447-69.

Bernheim, B. (1987), 'Ricardian Equivalence: An Evaluation of Theory and Evidence', NBER Macroeconomics Annual, MIT Press, Massachusetts.

Brixi, H. and Schick, A. (2002), Government at Risk: Contingent Liabilities and Fiscal Risk, World Bank, Washington DC.

Demirguc-Kunt, A. and E. Kane (2002), 'Deposit Insurance Around the Globe: Where Does It Work?', Journal of Economic Perspectives, 16(2):175-195.

Eichengreen, B. (2002), Financial Crises and What to Do About Them, Oxford University Press, Oxford, UK.

Fischer, S. and W. Easterly (1990), 'The Economics of the Government Budget Constraint', The World Bank Research Observer 5(3):127-42.

Giavazzi, F., T. Japelli and M. Pagano (2000), 'Searching for Non-linear Effects of Fiscal Policy: Evidence from Industrial and Developing Countries', European Economic Review 44:1259-89. 
Hemming, R., M. Kell, and A. Schimmelfennig (2003), Fiscal Vulnerability and Financial Crises in Emerging Market Economies, IMF Occasional Paper 218, IMF, Washington DC.

International Monetary Fund (2003a), Government Finance Statistics, IMF, Washington DC.

International Monetary Fund (2003b), World Economic Outlook, IMF, Washington DC, September, Chapter 3.

International Monetary Fund (2002), International Financial Statistics, IMF, Washington DC.

Makin, A. (1999), 'The Great East Asian Capital Flow Reversal: Reasons, Responses and Ramifications', The World Economy 22(3):407-419.

Munnel, A. (1992), 'Infrastructure Investment and Economic Growth', Journal of Economic Perspectives 6(4):223-245.

The author gratefully acknowledges the extensive constructive comments provided by two anonymous referees and the Editor, Graeme Wells. This article is based on research undertaken while he was at the IMF Singapore Training Institute in 2003-2004. 